\title{
CONSTRUCTION OF THE FOREST SCHOOL FRAMEWORK BASED ON INDIGENOUS KNOWLEDGE IN MALAYSIA
}

\author{
Norwaliza Abdul Wahab ${ }^{1 *}$, Pauline Swee-Choo Goh ${ }^{1}$, Eng-Tek Ong ${ }^{1}$, Mohd Hairy Ibrahim ${ }^{1}$, \\ Haryanti Mohd Affandi ${ }^{2}$ \\ ${ }^{1}$ Universiti Pendidikan Sultan Idris, Malaysia \\ ${ }^{2}$ Universiti Kebangsaan Malaysia, Malaysia \\ *e-mail: norwaliza@fpm.upsi.edu.my
}

\begin{abstract}
The rate of drop outs among indigenous or Orang Asli pupils in primary school is a worrying issue. They were found to be unable to apply the knowledge acquired through formal education systems in Malaysia due to the different ,settings' of the environment. This failure was due to the lack of understanding on how Orang Asli pupils learn, think, and act. The aim of this study was to construct a Forest School framework for the teaching and learning process in Orang Asli primary schools. The qualitative study design involved in-depth interviews with six experts from the Orang Asli community by using semi-structured questions to explore and clarify related sub-constructs. The results showed five elements that need to be incorporated in the syllabus, namely music, herbs and medicine, handicrafts, tools for hunting and forestry. The Forest School framework would serve as a comprehensive guide and reference for policymakers as indigenous knowledge elements need to be incorporated in primary school's syllabus to ensure life sustainability of Orang Asli in the forest. Teachers could take advantage to help Orang Asli pupils to feel more enthusiastic and motivated in processing the knowledge given in classrooms as it hits close to their environment.
\end{abstract}

\section{Keywords: education, forest school, indigenous knowledge, Orang Asli pupils}

\section{INTRODUCTION}

Forest school is an approach which is considered 'informal' or 'alternative' learning and blended with traditional curricula to create opportunities for children to experience learning outside of the classroom (Coates \& Pimlott-Wilson, 2019). According to Knight (2011), Jungle School or Forest School was first introduced in Sweden in the 1950's but was only conducted on kindergarten school children. As a result, the approach was successful in producing children with high social skills and self-esteem in addition to the ability to collaborate in group. This Forest School approach has been developed up to higher education levels (O'Brien \& Murray, 2007). Research conducted by Yatta (2007) showed that certain characteristics of indigenous cultural knowledge perspectives were incorporated into the Grade Nine social studies educational plan of a secondary school in a western Canadian city to evaluate the effect on academic accomplishment, class participation, and school retention among specific Aboriginal students' groups. The outcome showed cautious optimism about increasing academic accomplishment among these students by adding indigenous perspectives. Limitations of the learning environment within the school and the changing perception of the child and learning in this century also influenced educational policies, allowing teachers, academics and program development experts to discover the restrictive effect of school curricula limited by closed spaces on children's learning (Bergen, 2017).

The percentage of Orang Asli students' dropout continues to be a worrying issue in Malaysian education system (Wahab, Ahmad, \& Awang, 2019). According to Ma'rof \& Sarjit (2008) around 50 percent of the students from Orang Asli community do not further their study in secondary school and only 30 percent students of Orang Asli finish their secondary school. This is less than half of the national average (Kementerian Pendidikan Malaysia, 2012). Orang Asli students have failed to apply the knowledge obtained through the formal education system adapted from the West because of its 'settings' of different environments. Education of the Orang Asli is no longer a recent concern for the Ministry of Education Malaysia (MOE) and the Department of Orang Asli Development (JAKOA, 2012) but it can 
affected the government's goals in the Malaysian Education Development Plan 2013-2025 of their commitment to build students' accomplishment through a systematic education system for all (Ministry of Education, 2013). To realize the goals of Malaysia as a developed nation in 2020, the Orang Asli community should be brought together in developing a national agenda by combating issues or stereotypes against the Orang Asli community who had been perceived as the less advanced and backwards (Ma'rof \& Sarjit, 2008).

The educational accomplishment of the Orang Asli children has consistently been worrisome (Wahab, Mustapha, \& Ahmad, 2016; Hanafi, Ahmad, \& Ali, 2014). Majority of the Orang Asli in Peninsular Malaysia are still left behind especially in the education sector as compared to other races. Issues include learning disengagement and low academic achievement and the achievements have not been on the same level with national advancement (Md. Nor, Roslan, \& Mohamed, 2011). The study showed that nearly 50 per cent of Orang Asli students dropped out from school after six years of schoolings and only 30 per cent of the students have passed their secondary school education, which is less than half of the national average (Ministry of Education, 2013).

The reason behind the students dropping out and the reason why the Orang Asli students did not dominate the syllabus imparted by teachers was because they easily forgot what was taught in the classroom as the content were not what they can find near their surroundings. In the meantime, the teacher's inability to conduct effective teaching and learning activities was also found to have cause students' competency problem in reading, writing and comprehension skills. Besides, no special programs or modules were provided for the development of the Orang Asli Students' competency. As such, the Ministry of Education in Malaysia needs to develop a way to expose the Orang Asli students on the importance of education as well as for them to learn the indigenous knowledge so that they are not losing their identity as well. It has to be started from primary schools so that the interest can be nurtured and can be applied when they reach adulthood.

Therefore, the new approach known as the Forest School needs to be established.
In Europe, the implementation of the Forest School for minority communities is found to be effective in building self-confidence and attaining achievement through the learning of the indigenous communities. The elements of indigenous knowledge such as language, traditions, music, handicrafts, folk stories, flora and fauna should be included in the elementary education. This element can attract the interest of Orang Asli students to learn and master their knowledge and skills to ensure the survival of the forest. To date, it has been found that the Forest School has not been established in Malaysia and Asia formally. Hence, this study will construct a new framework as a guideline to build a Forest School 'setting' in the school. Besides that, the researchers also expected the Forest School's approach to enhance the ability of Orang Asli students in terms of attitude, knowledge and skills. Hence, the construction of this Forest School framework can be used as a complete guide for the school to implement the forestry environment, especially for the sustainability of the Orang Asli community.

\section{METHODS}

This study employed a qualitative approach to obtain empirical data in order to answer the research question. The in-depth interviews were conducted by the researchers with six experts from the indigenous community from four states in Malaysia to seek their view on the proposed framework of the Forest School. The opinions and views of these experts in this study were taken into consideration as they were active and keen in the indigenous studies. The selection of the study participants was based on the ability and willingness of the respondents themselves to provide the information needed to answer the research question (Creswell, 2013). The selected research participants were all well experienced in the indigenous knowledge, thus were able to help answer the research questions while providing additional information for the study.

In this study, purposive sampling technique was used to select the participants for in-depth interview sessions. This technique was chosen to select participants with characteristics and conditions that were predefined and individuals with extensive information in line with what needed to be studied. The sample must be fitting 
and consist of participants who best represent or is proficient on the research topic. Purposive sampling is appropriate for qualitative studies where the researcher is keen in informants who have the best knowledge concerning the research topic. When using purposive sampling, choices should be made about who or what is sampled, what structure the sampling should take, and what number of individuals or sites should be sampled (Creswell, 2013). In this study, six experts were identified based on the criteria aged from 50 to 60 years old. Three participants Tok Batin or Head of the village and three elderly people from various tribes were selected in this study and they need to be knowledgeable in indigenous knowledge and traditional practices from the Orang Asli tribe such as in music, tools, forestry, handicrafts and herbs. Table 1 shows the summary of the participants.

Data obtained via in-depth interviews usually implies a smaller sample. The objective of the interview is to deeply investigate the respondent's perspective, emotions and points of view. In this study, in-depth interviewing requires multiple repeated interview sessions with the intended interest participants under study. The data obtained from expert interviews were analyzed using deductive coding with predefined set of codes from the previous research. The recorded audio data were verbatim transcribed. The transcripts were checked twice for accuracy against the records, before starting the process of translation from Malay to English. The researcher had operated as a translation moderator and worked alongside a professional translator. This was done side-by-side where the researcher explained the intended meaning and its context in the source language while also discussing possible wordings (Van Nes, Abma, Jonsson, \& Deeg, 2010). The transcripts were analyzed by the thematic approach. A list of questions based on thematic concepts of Orang Asli indigenous knowledge was developed for applying a cluster analysis used to determine based on Orang Asli indigenous knowledge practices. The researcher selected to review informants' feedback analyzed these themes. After analyzing the theme, they were brought together and interpreted in relation to the purpose of this study.

\section{FINDINGS AND DISCUSSION}

The main finding of this study was the perception of the indigenous knowledge experts involved in this study. The data was gathered by interacting directly with the participants to understand their thoughts regarding to their knowledge hence to help developing or constructing the framework for the Forest School.

\section{Findings}

The experts have identified five elements to be included in the framework; (i) indigenous music, (ii) indigenous herbs and medicine, (iii) indigenous handicrafts, (iv) indigenous tools for hunting and, (v) indigenous forestry.

\section{Indigenous Music}

Orang Asli have come to understand that a declaration of their indigenous personality is important for their survival. One of the approaches to state this identity was to set up cultural troupes (including old and young Orang Asli communities) to perform indigenous music and dance. Tarian Sewang was played with buluh limbong a type of bamboo as a musical instrument. Most of their music was intended only for certain performances. This was because the succession and practice of music such as musical instruments and dances in the younger generation were increasingly

Table 1. Summary of the Participants

\begin{tabular}{lcccccc}
\hline Participant & $\mathbf{1}$ & $\mathbf{2}$ & $\mathbf{3}$ & $\mathbf{4}$ & $\mathbf{5}$ & $\mathbf{6}$ \\
\hline Gender & Male & Male & Female & Male & Male & Female \\
Age & 55 & 59 & 60 & 59 & 55 & 52 \\
Location & Pahang & Terengganu & Selangor & Perak & Selangor & Perak \\
Tribe & Semai & Batek & Mah Meri & Semai & Mah Meri & Semai \\
Skills & Tools & Forestry & Handicrafts & Music & Handicrafts & Herbs \\
Occupation & Tok Batin & Tok Batin & Housewife & Tok Batin & Farmer & Housewife \\
\hline
\end{tabular}


forgotten as the youngsters were not interested to learn how to play traditional music. They were already exposed to modern music when they go to primary schools such as guitar, drum, keyboard. Asan, a Tok Batin (head of village) from the Semai tribe in Perak stated, "This musical instrument played by a nose and we called it a nose flute. Only me and my son can play this flute in my village. We need more youth to learn this instrument so they can teach to their own children. Apart from that we also dance Tarian Sewang for special occasions and using buluh limbong while we are dancing." The findings showed that the Orang Asli community practiced music such as traditional dance like Tarian Sewang during certain time of the year. Tarian Sewang is the Malay term for Orang Asli religious ritual that involves music, dance, and singing (Chan \& Saidon, 2017).

\section{Indigenous Herbs and Medicine}

The results revealed that the use of indigenous herbs and medicine from certain species of plants as herbal medicine was still stringing in Orang Asli tribes. Few species of medicinal plants were identified near the respondent village such as Ketum, Bunga Raya Dukung Anak, Pegaga, Hempedu Bumi, Telinga Kera, Tepus, Mahkota Dewa and Tongkat Ali. Tijah, a housewife from Semai Tribe in Perak has stated, "Ketum are usually for abdominal pain and diarrhea. Soak it and keep it first, then filter it. We use the Bunga Raya as medicine to cure fever. For those who are lack of blood, we use Tepus with red leaves for bathing and to consume. We use the herbs around us but nowadays children do not recognize these herbs. They are not interested as they could get medicine easily from the government clinic." In this study, they utilized herbs and medicinal plants to make natural remedies for replacing modern medicines. They still depended on traditional medicine cures as their essential source of medication in treating numerous diseases in their daily lives.

\section{Indigenous Handicrafts}

Handicraft refers to handmade products that have artistic and cultural attraction based on their material, design and workmanship. The findings indicated that Orang Asli tribes are very skillful and knowledgeable in recognizing the raw materials of their interest in crafting. They managed to preserve a tradition of spiritual woodcarving that is truly world-class in terms of the quality of its craft and artistry. They used weaved bamboo, rattan or nipah as roof and wall decorations of the house. Minah, a housewife from Mah Meri tribe has stated that, "We collect nipah leaves, dry it nicely and then weave it to make a mat or basket. I can make one mat a week but nowadays the problem is very hard to get the materials like mengkuang as you need to go further in the jungle." Meanwhile, the Mah Meri tribes situated in Selangor also have their own uniqueness and diversities of handicraft that were synonym with the natural environment in terms of conserving the sustainability of the environment. Abu, a farmer from Mah Meri tribe in Selangor stated: "During the times of our grandparents, we use bamboo if we want to pitch the tent. We either use bamboo, woods or leaves as they were easily to get from the jungle." Based on the findings of this study, the Mah Meri tribe in a good example of this as they have created various wood carvings such as wooden sculptures, shell decorations, jewelry craft, and wall weaving. In Pahang, Semai tribes' lifestyles were directly associated with the forest and they possessed their own distinctive thoughts on the forest resources.

\section{Indigenous Tools for Hunting}

Based on the analysis of themes obtained through interview data, each study participant believed that indigenous peoples are able to utilize forest products and have their own methods of collecting forest products and the ability to utilize forest produce. Their own method of collecting forest produce enabled indigenous people to survive in the forest or suburban area. Orang Asli also use sumpit or blowpipe to hunt the animals like monkey, wild boar and deer for their meat and $b u b u$ to catch fish in the river. Alang, a Tok Batin from Pahang has stated that, "We use the long wooden sumpit (blowpipe) to hunt in the jungle. We use a type of poison from a tree called ipoh in the sumpit. If we want to catch fish, we use bubu, a tool for catching fish in the river. We need to teach our children how to learn. If not, they cannot survive in this jungle." According to Anyaoku, Nwafor-Orizu, \& Eneh (2015), these indigenous knowledges are taught in a conventional, oral and hands-on-generation 
basis and have transmitted from generation to generation. It's time for the Orang Asli students to get a basic knowledge about this indigenous knowledge in school.

\section{Indigenous Forestry}

Based on the analysis of themes obtained through interview data, each study participant believes that indigenous peoples are able to utilize forest products and have their own methods of collecting forest products and the ability to utilize forest produce. Atan, a Tok Batin from Bateq tribe in Terengganu stated, "We go to the jungle to collect bamboo shoots, rattan, petai and fruits for our own consumption or the extra we will sell." Their own method of collecting forest produce enabled indigenous people to survive in the forest or suburban area. "We only collected matured tree for wooden sculpture, or matured rattan to be harvested if not it will be a waste. Based on the data obtained, forest harvesting and collection methods were seen from the aspects of equipment used when collecting forest produce, derived forest produce, products that can be produced from forest produce and the methods used by Orang Asli community in keeping forest produce from plant enemies.

\section{Discussion}

The results and findings of this research show that the Orang Asli of these four states were still practicing indigenous knowledge as part of their lives. They played music but only for specific performance. This is because the inheritance and music practices such as musical instruments and dance among the younger generation have been forgotten and no longer interest by the younger generation. However, Chan \& Ching (2012), in her study found that their music contained a repository of wisdom, knowledge, and world views transmitted from a generation for thousands of years which were inspired by their natural environment. Therefore, it is very important to include indigenous music in the new framework for the Forest School for us to guarantee that this knowledge is not vanished for future generations.

The result identified that some Orang Asli tribes in Peninsular Malaysia still depended on forests and local natures in their daily life despite present modernization. The findings indicated that Orang Asli tribes were skillful, knowledgeable in maintaining and keeping the forest sustainability (Lambin, Wahab, Choo, Mustapha, Abdullah, \& Sharif, 2019). They looked for food in the forest, rattan, bamboo and fruits for them to sell and earn some money. Even though their younger generations were exposed to modernization, majority of the Orang Asli still depended on the forest to survive. They were experts in differentiating whether a fruit was edible or poisonous. They were also skillful in hunting animals. If these skills are partly developed in the Forest School, they would be able to continue to live in the jungle and maintain their life style as Orang Asli and can pass the knowledge to other generations.

Based on the findings, Orang Asli tribes utilized and maximized the use of medicinal plants for medicinal purposes to heal various health conditions in treating both children and adults (Lambin et al., 2019). Most of the medicinal plants are used in healing common ailments. The majority of the indigenous practitioners and the tribes especially the elder people preferred traditional ways of healing processes instead of relying on modern medicine from hospitals and rural clinics. They learned how to identify the herbs from their ancestors. As modernization and deforestation take place, many of the plants are very difficult to find. These herbs and plants should be introduced in the learning activities as it has many benefits for the Orang Asli community especially those who live in the remote area. They also picked and sold the herbs as an income as a traditional or alternative medicine to other community. Orang Asli tribes used these natural resources because they can easily get access to it. The Orang Asli schools need to participate and help them to restore this knowledge and make it interesting in their teaching and learning by introducing various types of herbs and medicine in their class activity.

The findings also found that the indigenous handicrafts were inspired by nature and surroundings which grow wildly and can be collected from the nearby areas of their settlement. Grobar (2017) emphasized that handicraft production has a vital role in many developing countries and highlights that the preservation and promotion of cultural and artistic traditions, as numerous abilities involved in the production of traditional products, have 
been inherited from era to era. This is because the ancestors have lived and worshipped the forest for the sake of their survival and for future generations and as well as utilized their surrounding for the sustainability of the environment. Most of the handicraft products which have the elements of environmental sustainability are for personal use. Besides, they also utilized all the available natural resources for various purposes of daily utility. As such in Jambi, Jangki (traditional carrier for women)) that is used to carry equipment and food to the paddy fields are still in used, nowadays, by some people despite the modern lifestyle (Andesmora, Muhadiono, \& Hilwan, 2017).

In their perspectives and myths, every craft has a different story of the spirit world and this shaped their belief and culture. The Orang Asli pupils should learn how to do weaving or wood carving as part of their learning in the classroom so they can proudly show their skills. The crafts are rich in history and culture and reflect their identity. In wood carving, all creation and creativity are based on nature and their beliefs. As for the hunting tools, hunting and fishing tools need to be introduced as part of the Orang Asli economic activities. Not all Orang Asli students will make it in their academic attainment. They still need to depend on the jungle for their sustainability especially by the Orang Asli living in remote areas.

This research focused on the opinions of the Tok Batin and the elderly people from various Orang Asli tribes to dig out the elements of the indigenous knowledge that should be included in the Forest School framework for Orang
Asli pupils. All the parts of the Forest School mezzo-system such as family, teacher, school administrators and education experts are needed so that a holistic perspective including different viewpoints of the Forest School can be introduced to the literature. Among the other elements that will be included in the Forest School framework is from the concept of indigenous knowledge which includes indigenous music, forestry, herbs and medicine, handicrafts and tools for hunting as shown in Figure 1.

In addition, Forest Schools are longterm establishments built in a forest or a natural environment having periods that are continuous rather than as occasional school in order to create a strong bond between children and natural life. Interviews were conducted with 33 children from two mainstream primary schools in England who had completed a six weeks Forest School program. A rigorous phenomenological thematic analysis revealed three inter related themes: a break from routine; learning through play; collaboration and teamwork (Coates \& PimlottWilson, 2019).

While formal school curriculum emphasizes on skills and knowledge, Forest School has a hidden curriculum concerned with the character and moral development of the students (Nadaraj, 2014). The findings suggest that the blending of Forest School with mainstream settings contributes to children's social, cognitive, emotional and physical skill development through experiential learning using play. The pedagogy of the Forest School offers a learning experience that fits the nature of the young children as it provides learning

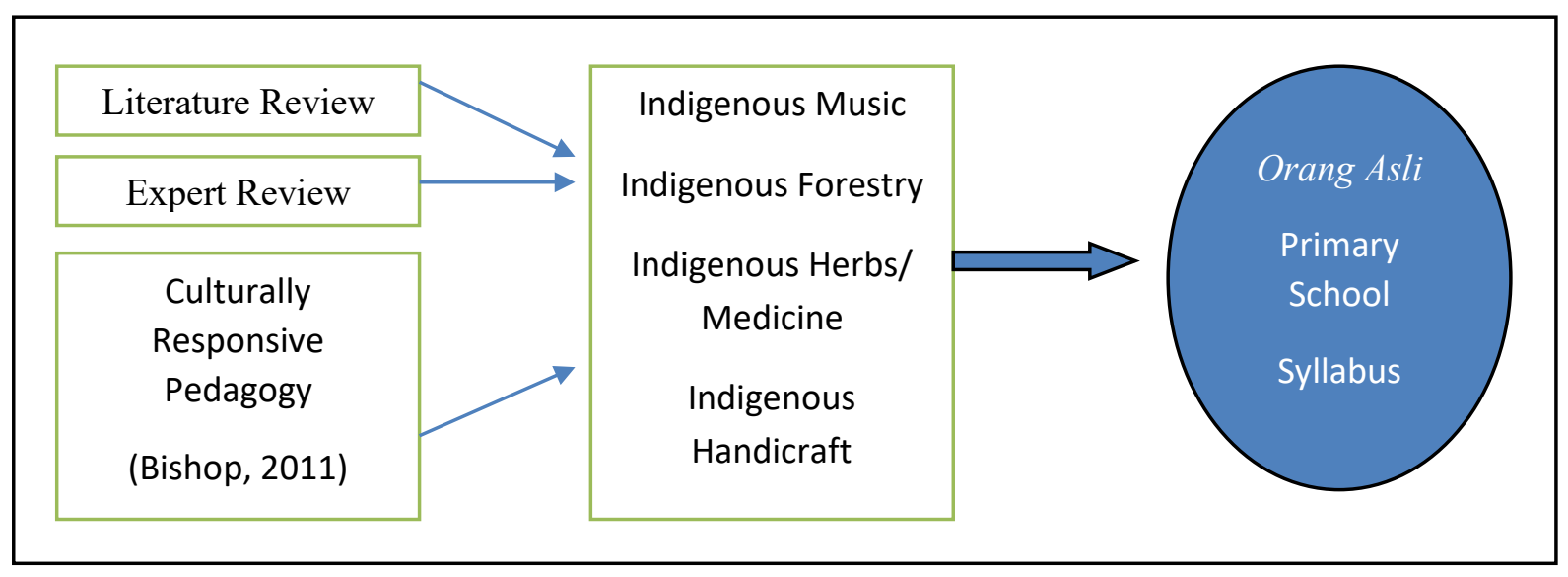

Figure 1. Forest School Framework 
experience which is both enjoyable and promotes discovery (Kahriman-Pamuk \& Ahi, 2019). One of the most important principles of naturebased approaches such as the Forest School is to strengthen children's bond with nature (Ernst \& Theimer, 2011; Otto \& Pensini, 2017). School would become the main foundation in growing awareness of environmental cultured education (Siswanto, Karimullah, Prasetyawati \& Nurhayati, 2019). This statement is supported by Ridgers, Knowles, \& Sayers (2012), which promotes learning in the natural environment for children to increase their acceptance of their education.

Children who love and protect their natural environment also could learn many things about the ecosystem in their learning processes. Another element of the forest school approach is that it allows children to play outside in natural environments. The forest offers children a space where they can move freely and have fun (Ridgers et al., 2012). Therefore, the cooperation of all parties is required to make the most of the Forest School in Malaysia including the teachers to improve the quality of learning through various learning approaches and methods. The teachers also need to be more efficient in maximizing their potential so their time and energy do not run out to deliver the material (Novianti \& Suparman, 2019).

The learning location is a fun school forest which has a tremendous and positive impact on the changes and potential development of the individual. The opinion was supported by MIND (2007) that found that the natural and genuine external environment would have a profound and beneficial impact on the individual. However, the safety aspect should be given attention, especially when involving child participation. Security will be able to give confidence to the participants of the forest schools and the transparency in experience sharing will be available. The speciality of the Forest Schools as compared to other classroom learning activities is from the consistency of its implementation. This to ensure that the activities of the forest can make changes to the behaviour of participants, activities should be done consistently at least once a week for 8 weeks or more (O'Brien, 2009; Knight, 2013). To provide a meaningful experience to the forest school, the concept of playing and learning should be used as a core for the activities. The concept of playing while learning is essential especially for children to develop themselves, take responsibility and to feel appreciated (Else, 2009).

\section{CONCLUSION}

The results lead to a conclusion that the component in the Forest School framework should cover the aspect of creativity and innovation in teaching and learning to reduce the rate of dropout and increase students' academic achievement. The application of Forest School element helps to expose Orang Asli students to their indigenous knowledge as Orang Asli as well as to preserve the customs and cultural heritage that will be focused on the younger generations. This framework should be implemented at the primary school level to be used as a teaching guide in school so that it can attract the interest of Orang Asli students to learn. Also, this framework should be disclosed to the public so that the Orang Asli's heritage and customs can be preserved. The development of the Forest School framework was necessary because the elements in this model framework are based on the Orang Asli's indigenous knowledge. The setting of a Forest School framework based on Orang Asli indigenous knowledge in this study is thought to be beneficial to the society where this framework can be used as a guide by the Government, Ministry of Education and NGO to help Orang Asli students increase their knowledge, academic achievement and reduce the rate of dropouts and at the same time they do not lose their identity as Orang Asli.

\section{ACKNOWLEDGEMENT}

This research has been carried out under the Fundamental Research Grants Scheme (FRGS/1/2019/SSI09/UPSI/02/8) provided by the Ministry of Education of Malaysia. The authors would like to extend their gratitude to the Research Management and Innovation Centre (RMIC), Sultan Idris Education University (UPSI).

\section{REFERENCES}

Andesmora, E. V., Muhadiono, \& Hilwan, I. (2017). Ethnobotanical study of plants used by people in Hiang Indigenous Forest Kerinci, Jambi. The Journal of Tropical Life Science, 7(2), 95-101. doi:10.11594/ 
Jtls.07.02.02.

Anyaoku, E. N., Nwafor-Orizu, O. E., \& Eneh, E. A. (2015). Collection and preservation of traditional medical knowledge: Roles for medical libraries in Nigeria. Journal of Library and Information Sciences, 3(1), 33-43. doi:10.15640/jlis.v3n1a2.

Bergen, D. (2017). Technology and outdoor play: Concenrs and opportunities. In T. Waller, E. Arlemalm-Hagsér, E. B. H. Sandseter, L. Lee-Hammond, K. Lekies, \& S. Wyver (Eds.). Handbook of outdoor play and learning. London: Sage, pp. 55-68

Bishop, R., \& Berryman, M., \& Wearmouth, J., \& Peter, M. (2012). Developing an effective education reform model for indigenous and other minoritized students. School Effectiveness and School Improvement, 23(1), 49-70. doi:10.1080/09243453.201 1.647921 .

Boyatzis, R. E. (1998). Transforming qualitative information: Thematic analysis and code development. Thousand Oaks, CA: Sage Publications.

Chan, C. S. C., \& Saidon, Z. L. (2017). Advocating contemporary traditional indigenous Semai music through an exploration of youth interest. International Journal of Academic Research in Business and Social Sciences, 7(7), 454-463. doi:10.6007/ IJARBSS/v7-i7/3114.

Chan, C., \& Ching, S. (2012). P. Ramlee's music: An expression of local identity in Malaya during the mid-twentieth century. Malaysian Music Journal, 1(1), 16-32. http://ejournal.upsi.edu.my/index. php/MJM/article/view/561.

Creswell, J. W. (2013). Qualitative inquiry and research design: Choosing among five approaches. Thousand Oaks, CA: Sage.

Coates, J. K., \& Pimlott-Wilson, H. (2019). Learning while playing: Children's forest school experiences in the UK. British Educational Research Journal, 45(1), 2140. doi:10.1002/berj.3491.
Else, P. (2009). The value of play. London: Continuum.

Ernst, J., \& Theimer, S. (2011). Evaluating the effects of environmental education programming on connectedness to nature. Environmental Education Research, 17(5), 577-598. doi:10.1080/13504622.2 011.565119 .

Fabeil, N. F., Pazim, K. H., Marzuki, K. M., \& Langgat, J. (2014). The orientation of handicraft entrepreneurs in Sabah: Their personality characteristics and motivations. Paper presented at $2^{\text {nd }}$ Asean Entrepreneurship Conference 2014, At Shangri-la Rasa Sayang Resort, Penang, Malaysia.

Grobar, L. M. (2017). Policies to promote employment and preserve cultural heritage in the handicraft sector. International Journal of Cultural Policy, 25(4), 1-13. doi:10.1080/10286632.2017.1330887.

Hanafi, W. A. W, Ahmad, S., \& Ali, N. (2014). Faktor budaya dan persekitaran dalam prestasi pendidikan anak Orang Asli Malaysia: Kajian kes di Kelantan. Geografia: Malaysian Journal of Society and Space, 10(5), 107-122. http://www. ukm.my/geografia/images/upload/10x. geografia-okt14-wanafizi-edam.pdf.

JAKOA (Jabatan Kemajuan Orang Asli). (2011). Pelan strategik kemajuan Orang Asli 2011-2015 (Report No. LAP0003050). Kuala Lumpur: Author.

Kahriman-Pamuk, D., \& Ahi, B. (2019). A phenomenological study on the school concept of the children attending the forest school. Journal of Qualitative Research in Education, 7(4), 1386-1407. doi: 10.14689/issn.2148-2624.1.7c.4s.4m.

Knight, S. (2011). Forest school for all. London: Sage.

Knight, S. (2011). Forest School as a way of learning in the outdoors in the UK. International Journal for CrossDisciplinary Subjects in Education (IJCDSE), 1(1), 590-595. doi:10.20533/ 
ijcdse.2042.6364.2011.0082.

Knight, S. (2013). International perspectives on forest school: Natural places to play and run. London: Sage.

Lambin, R., Wahab, N.A., Choo, G. S., Mustapha, R., Abdullah, R., \& Sharif, R. M. (2019). Transmission and documentation of Orang Asli indigenous knowledge in 'green technology' for sustainable development in Malaysia. International Journal of Academic Research Business and Social Sciences, 9(5), 195-213. doi:10.6007/ IJARBSS/v9-i5/5850.

Ma'rof, R., \& Sarjit S., G. (2008). Orang Asli: Isu, transformasi dan cabaran. [Orang Asli: Issues, transformations and challenges]. Serdang: UPM Press.

Md. Nor, S., Roslan, S., Mohamed, A., Abu Hassan, K., Mat Ali, M. A., \& Abdul Manaf, J. (2011). Dropout prevention initiatives for Malaysian indigenous Orang Asli children. The International Journal on School Disaffection, 8(1), 4256. doi:10.18546/IJSD.08.1.07.

MIND (Mental health association). (2007). Ecotherapy: The green agenda for mental health. London: Author.

Ministry of Education Malaysia. (2013). Malaysia education blueprint 2013-2025 (Preschool to post-secondary education). Kuala Lumpur: Author.

Nadaraj, S. (2014). Assessing student's socialization processes through hidden curriculum in schools. Asian Journal of Assessment in Teaching and Learning, 4(2014), 1-18. http://ejournal. upsi.edu.my/index.php/AJATeL/article/ view/1958.

Novianti, N., \& Suparman, S. (2019). Educational game design to improve reasoning skills. Asian Journal of Assessment in Teaching and Learning, 9(2), 1-8. doi:10.37134/ ajatel.vo19.no2.1.2019.

O'Brien, L., \& Murray, R. (2007). A marvellous opportunity for children to learn: $A$ participatory evaluation of Forest School in England and Wales. Hampshire: Forest Research.

O'Brien, L. (2009). Learning outdoors: The Forest School approach. Education 3-13, 37(1), 45-60. doi:10.1080/03004270802291798.

Otto, S., \& Pensini, P. (2017). Naturebased environmental education of children: Environmental knowledge and connectedness to nature, together, are related to ecological behavior. Global Environmental Change, 47(November), 88-94. doi:10.1016/j. gloenvcha.2017.09.009.

Pound, L. (2011). Influencing early childhood education. New York, NY: Open University Press McGraw-Hill.

Ridgers, N. D., Knowles, Z. R., \& Sayers, J. (2012). Encouraging plays in the natural environment: a child-focused case study of forest school. Children's Geographies, 10(1), 49-65. doi:10.1080/14733285.2011 .638176 .

Savage, C., Hindle, R., Meyer, L. H., Hynds, A., Penetito, W., \& Sleeter, C. E. (2011). Culturally responsive pedagogies in the classroom: Indigenous student experiences across the curriculum.Asia-Pacific Journal of Teacher Education, 39(3), 183-198. doi :10.1080/1359866X.2011.588311.

Siswanto, S., Karimullah, K., Prasetyawati, R., \& Nurhayati, N. (2019). Environmental cultured education and its implication on the student's competencies in an Adiwiyata school. Cakrawala Pendidikan, 38(3), 552-564. doi:10.21831/cp.v38i3.23154.

Van Nes, F., Abma, T., Jonsson, H., \& Deeg, D. (2010). Language differences in qualitative research: is meaning lost in translation? European journal of ageing, 7(4), 313-316. doi:10.1007/ s10433-010-0168-y.

Wahab, N. A., Ahmad, A. R., \& Awang, M. (2019). Pembangunan pendidikan Orang Asli di Malaysia. [Development of Orang Asli education in Malaysia]. Bangi: 
Penerbit Universiti Kebangsaan Malaysia.

Wahab, N. A., Mustapha, R., \& Ahmad, R. A. (2016). The roles of administrators in aboriginal schools: A case study in a Malaysian State. International Journal of Social Science and Humanity, 6(5), 370374. doi:10.7763/IJSSH. 2016. V6.674.
Yatta, K. (2007). Increasing school success among aboriginal students: Culturally responsive curriculum or macrostructural variables affecting schooling? Diaspora, Indigenous, and Minority Education, 1(1), 21-41. doi:10.1080/15595690709336599. 